\title{
Growth, flowering, and population dynamics of temperate Western Australian seagrasses
}

\author{
Núria Marbà ${ }^{1, *}$, Diana I. Walker ${ }^{2}$ \\ ${ }^{1}$ Institut Mediterrani d'Estudis Avançats (CSIC-UIB), Carretera de Valldemossa km 7.5, E-07071 Palma de Mallorca \\ (Illes Balears), Spain \\ ${ }^{2}$ Department of Botany, The University of Western Australia, Nedlands, Western Australia 6907, Australia
}

\begin{abstract}
Quantification of module size, leaf, rhizome and clonal growth, flowering intensity and shoot population dynamics of 7 temperate Western Australian seagrasses (Amphibolis antarctica, A. griffithii, Posidonia australis, P. sinuosa, P. angustifolia, Heterozostera tasmanica, Thalassodendron pachyrhizum) developing 8 monospecific stands reveals that these plants have different plant morphologies, display a wide repertoire of growth patterns, and exhibit substantial variability in their capacity to flower. Leaf production rate ranged between $2.6\left(P\right.$. sinuosa) and 26 leaves $\mathrm{yr}^{-1}$ (A. antarctica), and leaf life-span varied between 85 (A. antarctica) and $245 \mathrm{~d}$ ( $P$. sinuosa). Most of the species extended their horizontal rhizomes at rates slower than $10 \mathrm{~cm} \mathrm{yr}^{-1}$ The highest rate of new short shoot formation by vertical rhizomes was observed in $A$. antarctica (on average each vertical rhizome annually produced 1.5 new short shoots), and the lowest in $T$. pachyrhizum (only 1 new short shoot would be recruited from 65 vertical rhizomes). Horizontal rhizomes produced 1 new short shoot every 17 (H. tasmanica) or 582 d (P. sinuosa). Flowering intensity varied from 0 ( $P$. sinuosa) to $7 \%$ flowering short shoots $\mathrm{yr}^{-1}(P$. australis). The median age of the short shoots in these populations ranged from $367(H)$ tasmanica) to $1000 \mathrm{~d}$ ( $P$. sinuosa). Clonal growth was the main mechanism providing short shoots in these temperate Western Australian meadows. Short shoot recruitment balanced short shoot mortality rate in most populations, indicating that they were in steady-state with the colonisation process. These species maintain their meadows through different plant strategies as a result of their different growth programmes and the variability in sexual reproduction success. The large differences in flowering intensity found across temperate Western Australian seagrasses suggest that sexual reproduction may play an important role for meadow maintenance and recovery.
\end{abstract}

KEY WORDS: Amphibolis sp. Heterozostera tasmanica Posidonia sp. Thalassodendron pachyrhizum Leaf growth Rhizome elongation. Flowering intensity Demography

\section{INTRODUCTION}

The coastal zone of the temperate region of Western Australia is covered by extensive seagrass meadows comprising one-third of the global seagrass flora (den Hartog 1970, Larkum \& den Hartog 1989). Despite the importance and high diversity of seagrass communities in Western Australia (e.g. Kirkman \& Walker 1989), the rates of clonal growth and sexual reproduction of these seagrass species remain largely unknown.

·E-mail: marba@ceab.csic.es
Seagrass meadows are formed by genets, ramets, and their modules (i.e. leaves, rhizome internodes, roots). Genet production depends on the success of sexual reproduction, and, hence, on flowering rates, fertilisation success and seedling survival. Ramet and module production rely on clonal growth patterns (Tomlinson 1974, Duarte \& Sand-Jensen 1990, Marbà \& Duarte 1998), which regulate the rate of addition and size of these seagrass components. The balance between production and death of genets, ramets and modules allows the persistence of seagrass meadows over millennia (Larkum 1976). Conversely, the imbalance between production and loss of seagrass com- 


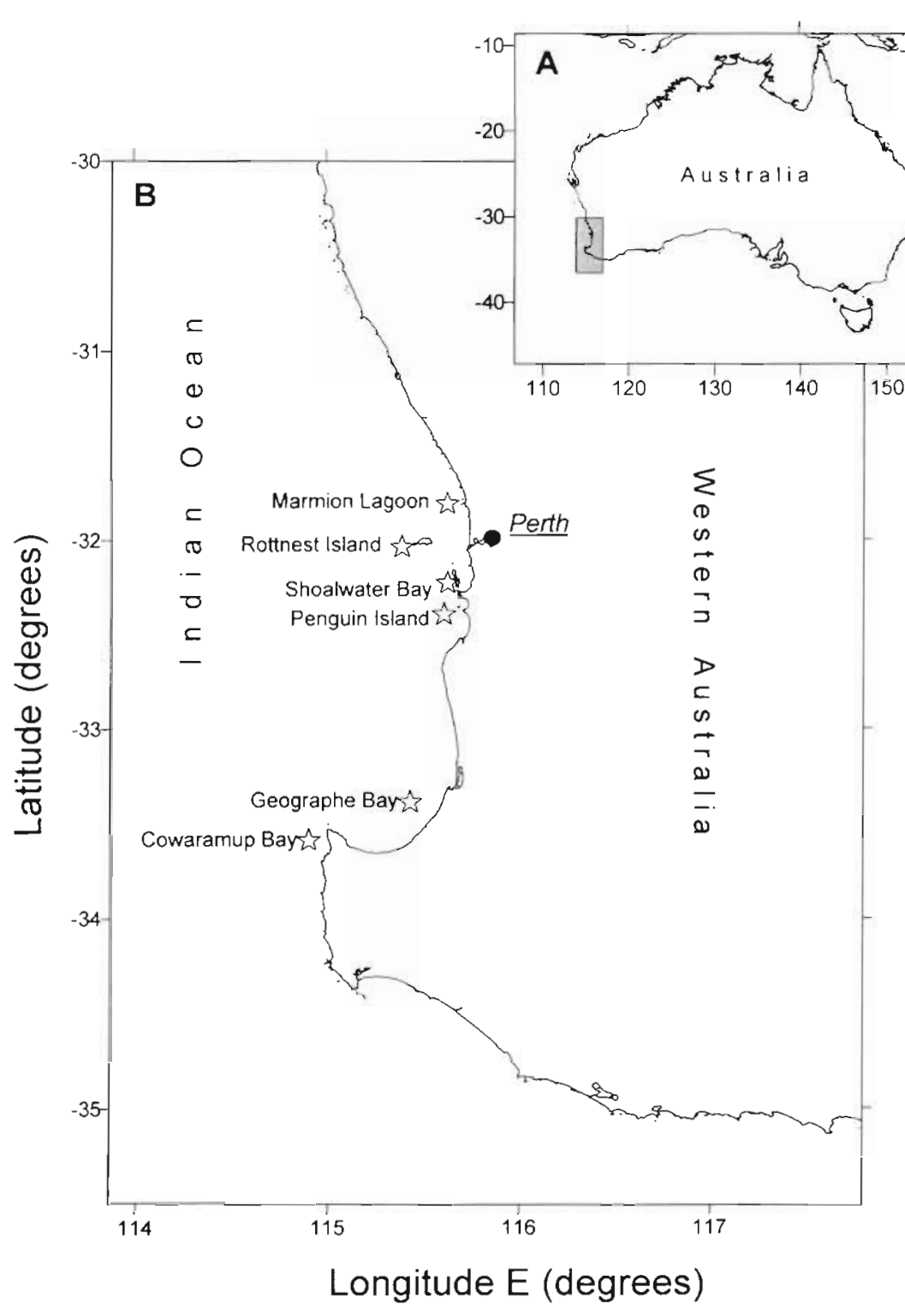

Fig. 1 Location of the area studied in (A) Australia, and location of the seagrass meadows examined along (B) the temperate Western Australian coast

ponents leads to the decline or expansion of seagrass populations (Duarte \& Sand-Jensen 1990). Hence, quantification of sexual reproduction success, shoot population dynamics and plant growth are the key to estimating productivity, as well as forecasting the expansion, persistence or decline of seagrass meadows (Duarte et al. 1994). However, only Clarke \& Kirkman (1989), Hillman et al. (1995), Waycott et al. (1996), Cambridge \& Hocking (1997) and Inglis \& LincolnSmith (1998) have quantified rhizome elongation and flowering intensity for a few of the temperate Western Australian seagrass species.
Seagrass growth rates have been demonstrated to be largely speciesspecific, although they also have adaptive value (Duarte 1991). Available studies quantifying seagrass flowering intensity also demonstrate that reproductive effort varies greatly across species and sites (e.g. Gallegos et al. 1992, Cambridge \& Hocking 1997, Inglis \& Lincoln-Smith 1998). Differences in the relative growth of different seagrass modules, and variability in sexual reproduction success across species may lead to contrasting strategies to maintain their meadows. Recent studies examining the genetic variability of temperate Western Australian seagrass populations, for instance, have revealed large differences in the degree of clonality among species (Waycott 1995, Waycott et al. 1996), suggesting that sexual reproduction may contribute differently to the maintenance of seagrass meadows depending on the species.

We here quantify seagrass leaf, rhizome and clonal growth, flowering intensity, as an upper threshold to sexual reproduction, and shoot demography of 7 temperate Western Australian seagrass species, growing in 8 developed monospecific meadows, using seagrass growth reconstructing techniques (Duarte et al. 1994). We demonstrate substantial differences in leaf, rhizome and clonal growth, flowering and shoot demography across temperate Western Australian seagrass species, which result in different strategies for meadow maintenance.

\section{METHODS}

During February and March 1995 we sampled 8 monospecific seagrass meadows distributed along $230 \mathrm{~km}$ of the south Western Australian coast. We collected Amphibolis antarctica at Parker Point (Rottnest Island), A. griffithii and Posidonia australis at Shoalwater Bay (Warnbro Sound), $P$. sinuosa at Penguin Island (Warnbro Sound) and Wonnerup Estuary (Geographe Bay), $P$. angustifolia and Heterozostera tasmanica at Marmion Lagoon, and Thalassodendron pachyrhizum at Cowaramup Bay (Figs. 1 \& 2). We harvested these plants from water depths ranging from 1 to $5 \mathrm{~m}$. The waters at these study sites are continental shelf waters of tropical and subtropical origin (Jeffrey 1981), with low levels of nutrients $\left(0.19 \mu \mathrm{mol} \mathrm{I} l^{-1} \mathrm{PO}_{4}, 0.19 \mu \mathrm{mol} \mathrm{l} l^{-1} \mathrm{NO}_{3}^{-}, 0.39 \mu \mathrm{mol} \mathrm{l} l^{-1}\right.$ $\mathrm{NH}_{4}{ }^{+}$, McMahon \& Walker 1998) and temperatures ranging from 15 to $22^{\circ} \mathrm{C}$ (McMahon et al. 1997). 


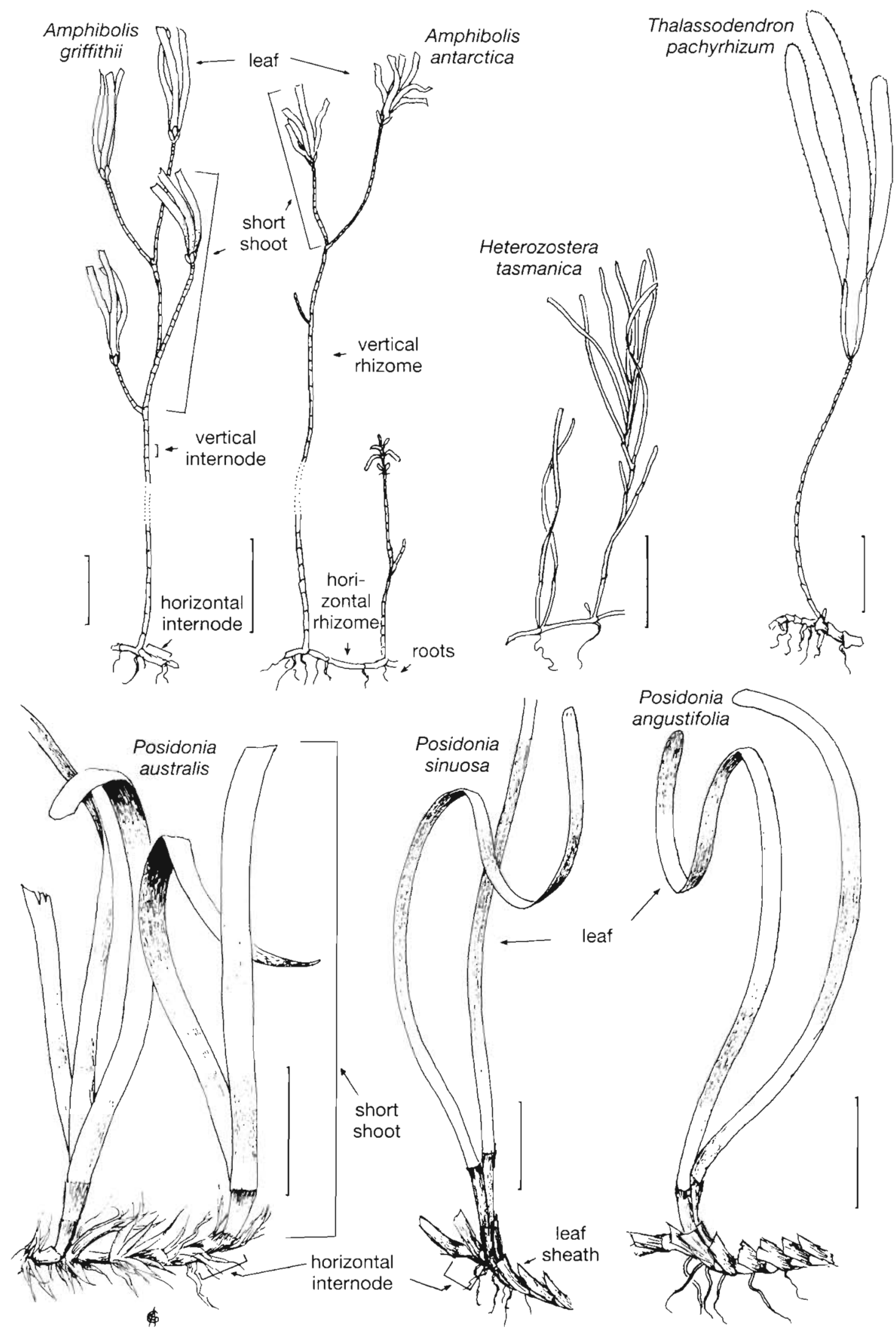

Fig. 2. Ramet and module morphology of the Western Australian seagrasses studied. Scale bars $=5 \mathrm{~cm}$, for all species 
In the inner part of each meadow and within about $50 \mathrm{~m}^{2}$, divers harvested more than 100 living short shoots (i.e. leaves plus vertical rhizome bearing them), all connected to 20-100 horizontal rhizome pieces, and measured short shoot density within 6 replicate $0.04 \mathrm{~m}^{2}$ quadrats. The plant material collected was transported to the laboratory for morphological measurements (i.e. number of standing leaves, vertical rhizome length, number of leaf scars of living short shoots, number of vertical branches, number of flowers and inflorescence scars, the length and internodes of horizontal rhizomes between consecutive short shoots, and the proportion of horizontal rhizome apices per shoot), measurement of module (leaf, rhizome internode, flower or inflorescence) dry weight after overnight desiccation at $85^{\circ} \mathrm{C}$, and examination of the age structure of living short shoots. These measurements allowed estimations of short shoot and horizontal rhizome apex density, module size, leaf formation rate and turnover time, vertical and horizontal rhizome growth, shoot vegetative proliferation rate, flowering intensity, short shoot age, short shoot recruitment and mortality rates, and population half-life. Horizontal rhizome apex density was derived from the product of short shoot density and the proportion of horizontal apices per short shoot found in the samples collected.

The average number of leaves produced per short shoot annually was estimated from the seasonal variability in vertical internodal length, examined on the vertical rhizomes of the 5 to 10 oldest living short shoots collected from each population. Identification of annual cycles in the length of vertical internodes, however, required short-term and interannual variability to be filtered out to emphasise the seasonal signal (Duarte et al. 1994). Therefore, we applied a high-and low-frequency filter to each raw data series (i.e. running averages of 30 and $150 \%$ of the expected number of internodes contained in a cycle). We then subtracted the low-frequency filtered series (i.e. the interannual component of vertical internodal length variability) from the high-frequency filtered one, and obtained the seasonal trend of vertical internode length. The seasonal trend of vertical internodal length appeared clear in all shoots examined. Because of the 1:1. relationship between leaf and vertical internode formation, the number of vertical internodes between 2 consecutive minima, or maxima, equals the number of leaves produced that year by a short shoot (Duarte et al. 1994). Comparison of the estimates of the annual number of leaves produced per shoot derived from seasonal fluctuations in the size of vertical internodes with those assessed using leaf-marking techniques (Table 1) demonstrated an excellent agreement between both estimates. Knowledge of the average number of leaves produced annually per short shoot in
Table 1. Estimates of the average number of leaves produced annually by short shoots of some studied Western Australian seagrasses, calculated from the seasonality in the size of vertical rhizome internodes (i.e. using reconstructing techniques), and by following the production of leaves per shoot for 1 yr (i.e. using leaf-tagging techniques). Standard error of. the mean is given within parentheses

\begin{tabular}{|lrc|}
\hline & \multicolumn{3}{c|}{$\begin{array}{c}\text { Number of leaves shoot }{ }^{-1} \mathrm{yr}^{-1} \\
\text { Reconstructing }\end{array}$} & Tagging \\
\hline Amphibolis antarctica & $26.1(0.89)$ & $32.0(0.28)^{\circ}$ \\
Amphibolis griffithii & $11.6(0.47)$ & $13.4(1.3)^{b}$ \\
Posidonia australis & $6.7(0.14)$ & $6.4(0.1)^{\mathrm{c}}$ \\
Posidonia sinuosa (Penguin Is.) & $2.6(0.07)$ & $2.1(0.1)^{\mathrm{c}}$ \\
${ }^{\mathrm{a}}$ Hillman et al. (1989), ${ }^{\mathrm{b}}$ Carruthers \& Walker $(1997)$, \\
${ }^{\mathrm{C} C a m b r i d g e} \&$ Hocking (1997)
\end{tabular}

each meadow during the short shoot life-span. allowed calculation of the annual average leaf plastochron interval (PI, the time elapsed between the formation of 2 consecutive leaves, Akenasy 1880), and, in turn, translation of time in plastochron to absolute time (i.e. days or years).

Because the oldest short shoots of Heterozostera tasmanica were younger than $2 \mathrm{yr}$, we calculated the leaf PI of this species using leaf-marking techniques. We selected 45 shoots of $H$. tasmanica and punched their leaves with a needle at the level of the petiole. After $8 \mathrm{~d}$ we harvested the punched shoots, and, in the laboratory, we counted the number of new leaves (i,e. those without a hole) and we estimated the leaf PI as,

Leaf PI $(\mathrm{d})=\frac{\text { number of punched shoots } \times \text { marking period }(\mathrm{d})}{\text { total number of new leaves }}$

Because we only estimated the leaf PI of $H$. tasmanica in late summer, i.e. the time of fast growth, the annual leaf formation rate calculated for this species, and, therefore, those parameters calculated using the $H$. tasmanica leaf PI may be overestimated. We estimated leaf turnover time as the average number of standing leaves during the sampling time divided by the average number of leaves produced annually per short shoot in each meadow

Vertical rhizome elongation was calculated by regressing the length of vertical rhizomes against short shoot age. The slope of the regression equation represented the vertical elongation rate. The rate of formation of horizontal rhizome internodes was estimated by regressing the number of horizontal internodes between pairs of short shoots connected by an horizontal rhizome piece against their age difference (Duarte et al. 1994). The maximum age difference between shoots connected was large, ranging from 2.5 to $5.8 \mathrm{yr}$ (Posidonia australis, Thalassodendron pachyrhizum, respectively). The slope of the fitted regression equa- 
tion represented the average number of horizontal rhizome internodes produced per leaf PI. Once the leaf $\mathrm{PI}$ is translated into days, the inverse of this slope equals the time the plant spends to produce a horizontal rhizome internode (i.e. horizontal rhizome plastochron interval, or rhizome PI). The product of this slope, the average length of a rhizome internode and the average annual rate of leaf formation provided an estimate of the average annual horizontal rhizome elongation rate (Duarte et al. 1994).

Amphibolis spp. and Thalassodendron pachyrhizum are dioecious plants producing single flowers, whereas Heterozostera tasmanica and Posidonia spp. are monoecious species that have inflorescences. We estimated seagrass flowering intensity by dividing the number of female flower marks on short shoots of Amphibolis spp. and $T$. pachyrhizum, and the number of inflorescence scars on short shoots of $H$. tasmanica and Posidonia spp., by the total number of leaf scars and standing leaves (i.e. the age) of living short shoots in the samples. The difficulty of distinguishing male flower marks from dead vertical branches in Amphibolis sp. and T. pachyrhizum prevented estimation of male flowering intensity of these species. The number of standing flowers and inflorescences found on the sampled short shoots were also added to the number of flowering marks. We multiplied the flowering intensity, as flowers per leaf PI (or inflorescences per leaf PI), by the inverse of the leaf PI (in yr) to calculate flowering intensity as flowers (or inflorescences) shoot ${ }^{-1} \mathrm{yr}^{-1}$.

The population dynamics of the meadow was characterised by the age distribution of living short shoots, and the calculated short shoot recruitment, short shoot mortality, and net population growth rates (cf. Duarte et al. 1994). Short shoot age was estimated as the product of the total number of leaves produced during the short shoot life-span (i.e. number of standing leaves plus number of leaf scars on the vertical rhizome supporting the shoot) multiplied by the leaf PI (in d). The annual gross short shoot recruitment rate $\left(R_{\text {gross }}\right.$ in units $\left.\mathrm{yr}^{-1}\right)$ was calculated as,

$$
R_{\mathrm{yross}}=\ln \sum_{t=0}^{\infty} N_{t}-\ln \sum_{t=1}^{\infty} N_{t}
$$

where $\sum_{i=0}^{\infty} N_{i}$ is the number of living shoots and $\sum_{i=1}^{\infty} N_{t}$ is the number of living shoots $>1 \mathrm{yr}$. Short shoot mortality rate $\left(M, \ln\right.$ units $\left.\mathrm{yr}^{-1}\right)$ was derived from the exponential decline in the abundance of living short shoots $\left(N_{0}\right)$ with time $(t$, in PIs) as,

$$
N_{t}=N_{0} \cdot \mathrm{e}^{-M \cdot t}
$$

where $N_{0}$ is the number of short shoots with age equal to the mode, and $N_{t}$ is the number of short shoots older than the modal age at time $t$ (cf. Sheil et al. 1995).
$M$ was estimated using a semilogarithmic linear regression model, where we assumed constant mortality over short shoot age classes and years. Thus, the mortality rates estimated here may be slightly altered if interannual fluctuations in shoot recruitment and mortality during short shoot life-span were significant (Duarte et al. 1994). The ratio between recruitment and mortality rates $(R / M)$ was used to indicate whether populations were expanding (i.e. $R / M>1$ ), declining (i.e. $R / M<1$ ) or in steady state (i.e. $R / M=1$; Duarte \& Sand-Jensen 1990, Duarte et al. 1994). We used the net rate of short shoot population growth $\left(R_{\text {net }}=R_{\text {gross }}-M\right.$; Duarte et al. 1994) to forecast the likely trend in the development of the meadows if growth conditions were maintained.

We used linear spline regression analysis to detect changes in vertical rhizome elongation rates during short shoot life-span (Freund \& Littell 1991). We examined the coupling between variables with Pearson correlation analysis.

\section{RESULTS}

The temperate Western Australian seagrasses examined showed contrasting sizes, with Heterozostera tasmanica being the smallest species and Posidonia spp. being the largest. Leaf and internode mass of temperate Western Australian seagrasses ranged over 2 and 3 orders of magnitude, respectively (Table 2). Leaf and rhizome internode mass were positively correlated (Pearson correlation, $r=0.85, p<0.01$ ). The number of standing leaves on seagrass short shoots varied 6-fold across the plants studied (Table 2).

Amphibolis spp., Heterozostera tasmanica and Thalassodendron pachyrhizum develop their canopies well above the sediment surface, with their vertical rhizomes extending in the water column and supporting, on average, 1 to 8 short shoots (Table 2). The canopy of Posidonia spp. is placed just above the sediment surface, with the leaf meristems being buried by sand. Despite the differences in module size and plant morphology, the ramet densities of the species were similar across populations, except for the $P$. sinuosa meadow growing in Geographe Bay (Tukey analysis, $p<0.0005$; Table 3). In contrast, the density of horizontal rhizome apices varied greatly across the meadows (Table 3). The leaf biomass maintained by these populations varied more than 10 -fold (Table 3 ), due to the large differences in leaf standing biomass per ramet between the species (Pearson correlation, $r=0.93, p<0.001$ )

The length of the vertical rhizome internodes of all the species studied here exhibited distinct seasonal cycles (Fig. 3). The seasonal cycles imprinted on the 
Table 2. Plant size of temperate Western Australian seagrasses. Standard error of the mean (within parentheses) is provided when possible. Mean mass of leaves and rhizome internodes was estimated from a pull with more than 30 modules (na: not available\}

\begin{tabular}{|c|c|c|c|c|c|c|c|}
\hline & \multirow{2}{*}{$\begin{array}{c}\text { Rhizome } \\
\text { diameter } \\
\text { (mm) }\end{array}$} & \multirow{2}{*}{$\begin{array}{c}\text { Short } \\
\text { shoots } \\
\text { per stem }\end{array}$} & \multirow{2}{*}{$\begin{array}{l}\text { Standing } \\
\text { leaves per } \\
\text { short shoot }\end{array}$} & \multicolumn{4}{|c|}{ Module mass (g dry wt) } \\
\hline & & & & Leaf. & $\begin{array}{l}\text { Horizontal } \\
\text { internode }\end{array}$ & $\begin{array}{l}\text { Vertical } \\
\text { internode }\end{array}$ & Flower \\
\hline Amphibolis antarctica & $2.60[0.09\}$ & 4.92 & $6.13(0.09)$ & 0.011 & 0.026 & 0.005 & na \\
\hline Amphibolis griffithii & $2.19(0.10)$ & 7.57 & $2.88(0.04)$ & 0.031 & 0.020 & 0.008 & na \\
\hline Heterozostera tasmanica & $1.97(0.18)$ & 1.86 & $3.82(0.08)$ & 0.007 & 0.009 & 0.002 & 0.001 \\
\hline Thalassodendron pachyrhizum & $5.64(0.16)$ & 1 & $2.80(0.05)$ & 0.206 & 0.061 & 0.001 & 0.043 \\
\hline Posidonia australis & $7.41(0.29)$ & 1 & $2.59(0.04)$ & 0.154 & 0.059 & 0.009 & na \\
\hline Posidonia angustifolia & $5.99(1.45)$ & 1 & $2.60(0.04)$ & 0.142 & 0.123 & 0.062 & na \\
\hline Posidonia sinuosa (Penguin Is.) & 5.59 (na) & 1 & $1.81(0.03)$ & 0.129 & 0.044 & 0.008 & na \\
\hline Posidonia sinuosa (Geographe Bay) & $5.46(\mathrm{na})$ & 1 & $1.96(0.03)$ & 0.153 & 0.072 & 0.016 & na \\
\hline
\end{tabular}

vertical rhizomes revealed large differences in leaf formation rates across the species examined. The time elapsed between formation of 2 consecutive leaves ranged between 14 (Amphibolis antarctica) and $141 \mathrm{~d}$ (Posidonia sinuosa) (Table 4). The leaves of temperate Western Australian seagrasses lived, on average, between 86 ( $A$. antarctica) and $254 \mathrm{~d}$ ( $P$. sinuosa), resulting in leaf turnover rates ranging from 1.4 to $4.25 \mathrm{yr}^{-1}$ (Table 4). The life-span of the leaves of temperate Western Australian seagrasses was positively, and strongly, coupled to leaf PI (Pearson correlation, $r=0.97, p<0.00005$ ), the leaves becoming shorterliving the faster they were produced.

The short shoots of the seagrass species studied were able to grow vertically. The vertical rhizomes of Posidonia spp., except $P$. sinuosa from Geographe Bay, elongated at rates slower than $10 \mathrm{~cm} \mathrm{yr}^{-1}$ (Table 4). The vertical elongation rate of Posidonia spp. was independent on short shoot age. Conversely, the vertical growth rate of Amphibolis spp., Thalassodendron pachyrhizum and Heterozostera tasmanica declined with short shoot age (Fig. 4). Vertical rhizomes of A. griffithii, A. antarctica and $T$. pachyrhizum elongated 34, 23, and $11.8 \mathrm{~cm} \mathrm{yr}^{-1}$ during the first year, respectively, whereas they only grew at rates of 16,11 and $4 \mathrm{~cm} y x^{-1}$, respectively, when short shoots became older (linear Spline regression analysis, $p<0.05)$. The decline in vertical growth with short shoot age was attributable to the formation of shorter vertical internodes (Fig. 4), and not to a decrease in leaf formation rate as shoots aged (Tukey analysis, $p>0.5$ ). The horizontal rhizome apices of temperate Western Australian seagrasses added new horizontal internodes at annual rates ranging over 1 order of magnitude. The fastest addition of new horizontal internodes was observed in $H$. tasmanica (13 $\mathrm{d}$ internode $\mathrm{e}^{-1}$, Table 4 ) and the slowest in $P$. sinuosa (158 d internode ${ }^{-1}$, Table 4). The large differences in internode formation rate (Table 4) and in internodal size (Table 2) among species resulted in horizontal rhizome elongation rates varying about 30 -fold (Table 4 ). Most of the horizontal rhizomes, however, extended at rates slower than $10 \mathrm{~cm} \mathrm{yr}^{-1}$ (Table 4).

Vertical and horizontal rhizomes produced short shoots as they elongated. However, the rate of short shoot proliferation differed greatly across species. Short shoot proliferation from vertical rhizomes was the fastest in Amphibolis antarctica (i.e. 1 new short shoot every $229 \mathrm{~d}$, Table 4 ), whereas only $1.5 \%$ of the vertical rhizomes of Thalassodendron pachyrhizum produced 1 new short shoot annually (Table 4). Conversely, vegetative proliferation by seagrass horizontal rhizomes was about 10 -fold faster than that from vertical ones, except for Amphibolis spp., in which the vertical rhizomes produced short shoots faster than the horizontal ones did (Table 4). The production of short shoots from horizontal rhizomes ranged from 1 new short shoot every 17 (Heterozostera tasmanica) to $582 \mathrm{~d}$

Table 3. Ramet and horizontal rhizome apex density and aboveground biomass in temperate Western Australian seagrass meadows. Standard error of the mean values (within parentheses) is provided when available

\begin{tabular}{|lccc|}
\hline & $\begin{array}{c}\text { Ramet } \\
\text { density } \\
\text { (ramets } \mathrm{m}^{-2} \text { ) }\end{array}$ & $\begin{array}{c}\text { Horizontal } \\
\text { apex density } \\
\left(\text { apices } \mathrm{m}^{-2} \text { ) }\right.\end{array}$ & $\begin{array}{c}\text { Leaf } \\
\text { biomass } \\
\left(\mathrm{g} \text { dry wt } \mathrm{m}^{-2} \text { ) }\right.\end{array}$ \\
\hline Amphibolis antarctica & $642(85)$ & 18 & 214.2 \\
Amphibolis griffithii & $788(91)$ & 24 & 531.7 \\
Heterozostera tasmanica & $625(40)$ & 58 & 30.5 \\
Thalassodendron pachyrhizum & $667(28)$ & 96 & 384.8 \\
Posidonia australis & $605(31)$ & 28 & 241.2 \\
Posidonia angustifolia & $692(36)$ & 276 & 254.6 \\
Posidonia sinuosa (Penguin Is.) & $413(61)$ & 60 & 96.2 \\
Posidonia sinuosa (Geographe Bay) & $1073(140)$ & 172 & 321.4 \\
\hline
\end{tabular}



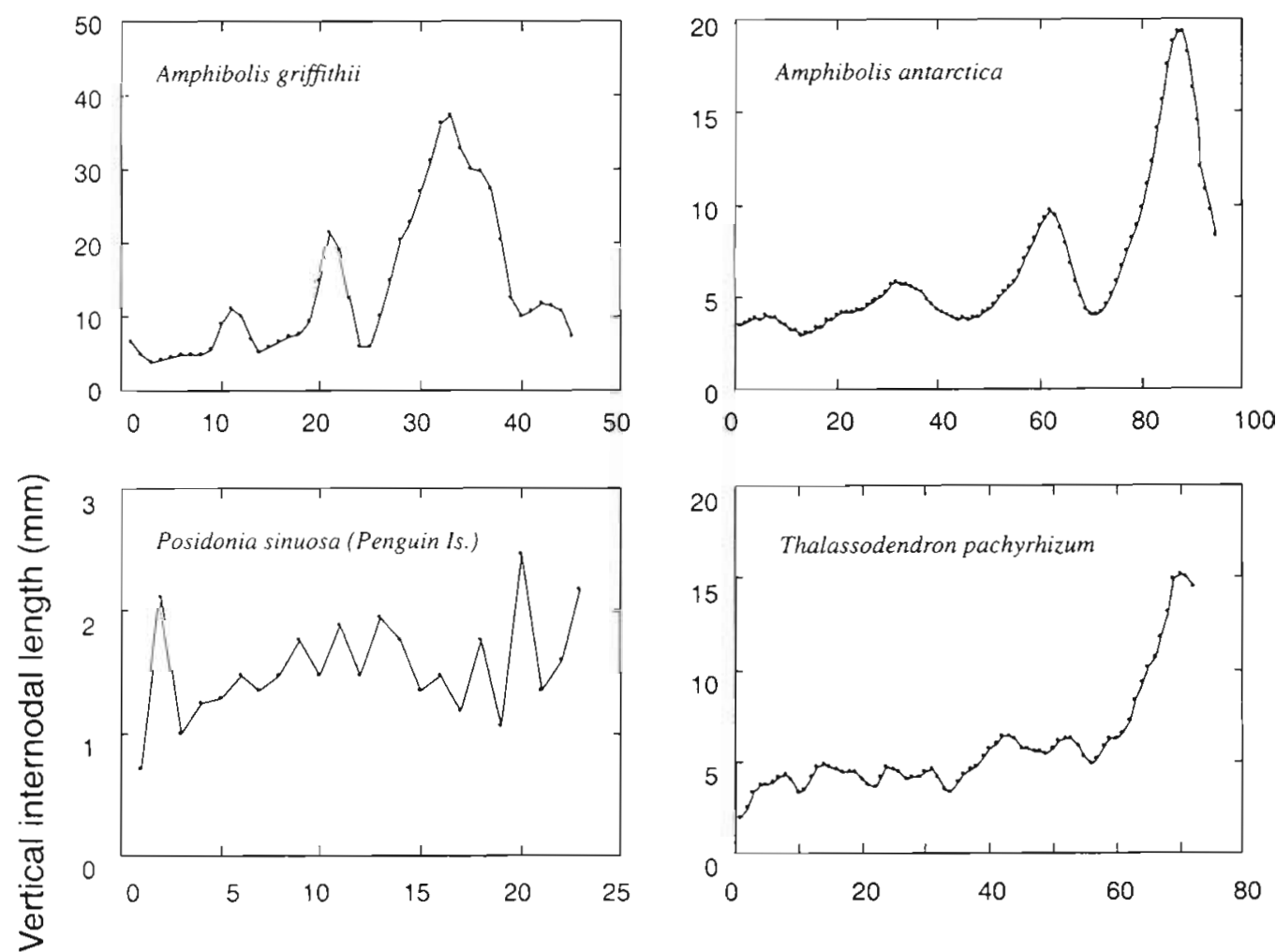

Fig. 3. Example of sequences of vertical internodal length measured on living short shoots of the seagrasses indicated. The time series started in reverse chronological order in February 1995
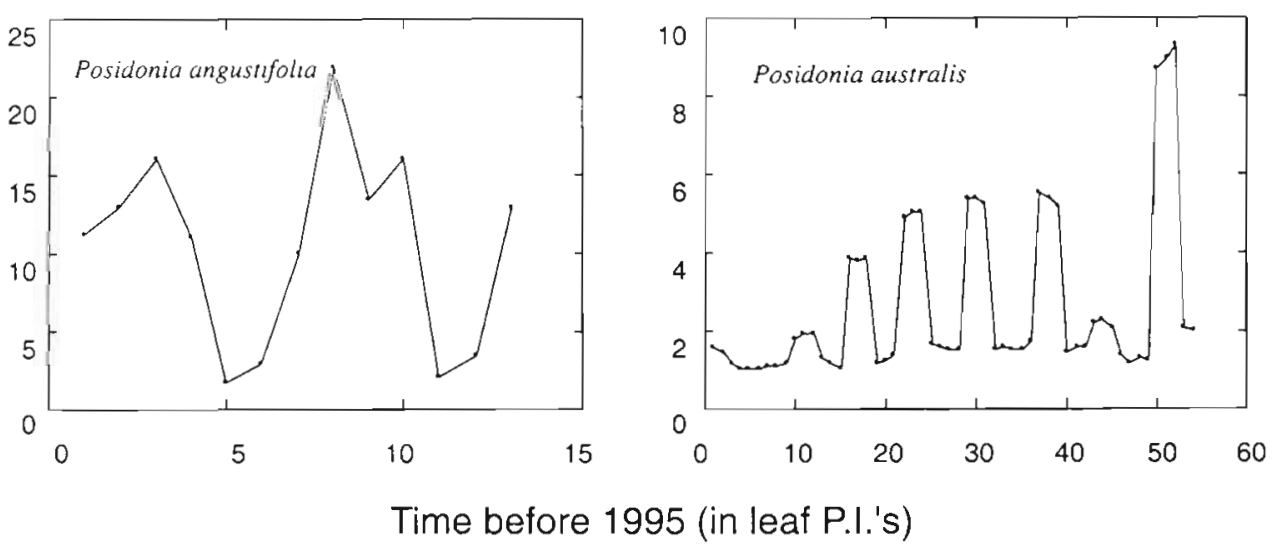

Table 4. Module growth of temperate Western Australian seagrasses (PI: plastochron interval)

\begin{tabular}{|c|c|c|c|c|c|c|c|c|}
\hline & $\begin{array}{l}\text { Leaf } \\
\text { PI t } \\
\text { (d) }\end{array}$ & $\begin{array}{l}\text { Leaf } \\
\text { turnover } \\
\text { time (d) }\end{array}$ & $\begin{array}{l}\text { Horizontal } \\
\text { rhizome PI } \\
\text { (d) }\end{array}$ & $\begin{array}{l}\text { Vertical } \\
\text { rhizome } \\
\text { elongation } \\
\left(\mathrm{cm} \mathrm{yr}^{-1}\right)\end{array}$ & $\begin{array}{l}\text { Horizontal } \\
\text { rhizome } \\
\text { elongation } \\
\left(\mathrm{cm} \mathrm{yr}^{-1}\right)\end{array}$ & $\begin{array}{l}\text { Vertical } \\
\text { shoot PI } \\
\text { (d) }\end{array}$ & $\begin{array}{l}\text { Horizontal } \\
\text { shoot PI } \\
\text { (d) }\end{array}$ & $\begin{array}{c}\text { Flowering } \\
\text { intensity } \\
(\% \text { of flowering } \\
\left.\text { shoots } \mathrm{yr}^{-1}\right)\end{array}$ \\
\hline Amphibolis antarctica & 14 & 85.9 & 48.3 & 15 & 5.5 & 229 & 256 & 0.18 \\
\hline Amphibolis griffithii & 31.6 & 90.9 & 87.7 & 16 & 4.3 & 277 & 509 & 3.3 \\
\hline Heterozostera tasmanica & $22.6^{\mathrm{a}}$ & & $12.8^{a}$ & $8.9^{3}$ & $55.7^{\mathrm{a}}$ & $487^{\mathrm{a}}$ & $17^{\mathrm{a}}$ & 1.3 \\
\hline Thalassodendron pachyrhizum & 30.8 & 86.3 & 64.2 & 6.4 & 2.7 & 23693 & 256 & 6.2 \\
\hline Posidonia australis & 54.4 & 140.9 & 52.8 & 1.4 & 9.3 & 1882 & 388 & 7.7 \\
\hline Posidonia angustifolia & 73.6 & 191.3 & 53.3 & 4.8 & 12.3 & 1335 & 199 & 0 \\
\hline Posidonja sinuosa (Penguin Is.) & 140.4 & 254.1 & 157.7 & 7.2 & 1.7 & 1786 & 582 & 0 \\
\hline Posidonia sinuosa (Geographe Bay) & 108 & 211.7 & 91.5 & 18 & 5.5 & 1845 & 357 & 0.31 \\
\hline
\end{tabular}



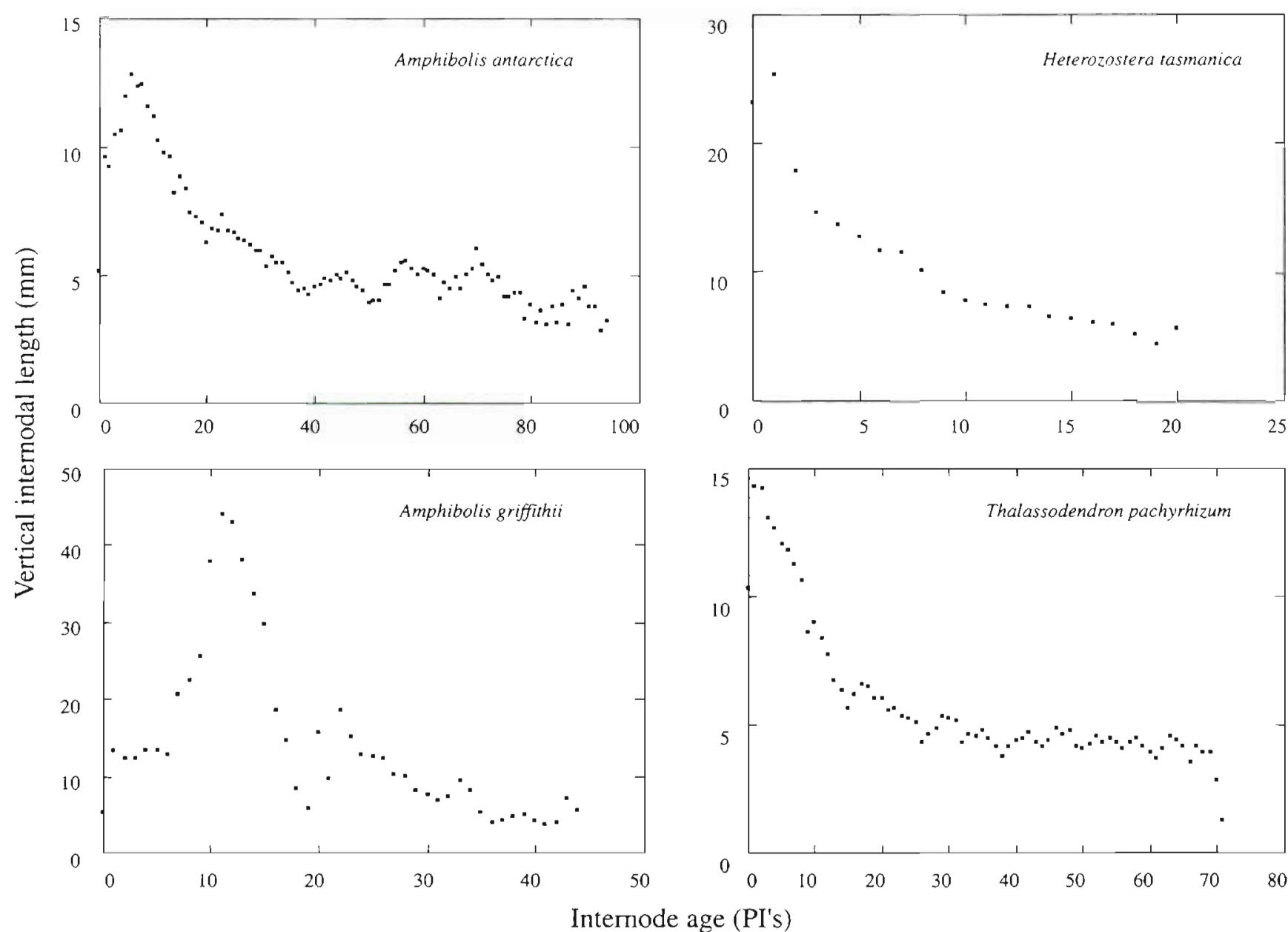

Fig. 4. Changes in mean internode length versus internode age in vertical stems of the seagrasses indicated. Mean internode length was calculated from 5 to 10 internodes. For clarity, error bars are not shown

(Posidonia sinuosa, Table 4). The variability in short shoot formation rate by horizontal rhizomes was largely (49\%) attributable to differences in the rhizome elongation rate between plants (Pearson correlation, $p<0.05$ )

The vertical rhizomes of all species, but Posidonia angustifolia and P. sinuosa in Penguin Is., presented flowering scars (Table 4). Moreover. Thaldssodendron pachyrhizum and Heterozostera tasmanica were flowering during the study period. The short shoots of most species only flowered once during their life-span, and only very few of the vertical rhizomes of $P$. australis and T. pachyrhizum presented 2 flowering scars. Flowering intensity across the species examined ranged between 0 $(P$. angustifolia and $P$. sinuosa at Penguin Is., Table 4 ) to $8 \%$ flowering short shoots $y^{-1}(P$. australis, Table 4$)$.

The short shoot age structure in most of the seagrass species was characterised by a high abundance of short shoots younger than 1 yr old followed by an exponential decline in short shoot abundance as short shoots aged (Fig. 5). However, short shoot age structure in Heterozostera tasmanica, Posidonia angustifolia and $P$. sinuosa slightly differed from this general pattern. All short shoots of the $H$. tasmanica population were younger than $1.5 \mathrm{yr}$ and, thus, the age structure of this population mainly reflected the seasonality in short shoot recruitment of the current year's cohort (Fig. 5). The abundance of the youngest shoots was low for the youngest age classes of $P$. angustifolia and $P$. sinuosa populations when compared with the abundance of older short shoots, suggesting a decline in short shoot recruitment for the 1 to 2 yr prior to sampling (Fig. 5). Most of the short shoots of Amphibolis spp., and half of those of $H$. tasmanica had been produced by vertical rhizomes (Fig. 5). The median age of living short shoots in the populations studied ranged from $367 \mathrm{~d}$ in $H$. tasmanica to $1000 \mathrm{~d}$ in P. sinuosa, although the maximum life expectancy of short shoots of all species, but $H$. tasmanica, exceeded $1000 \mathrm{~d}$ (Table 5). Short shoots produced from branching of 

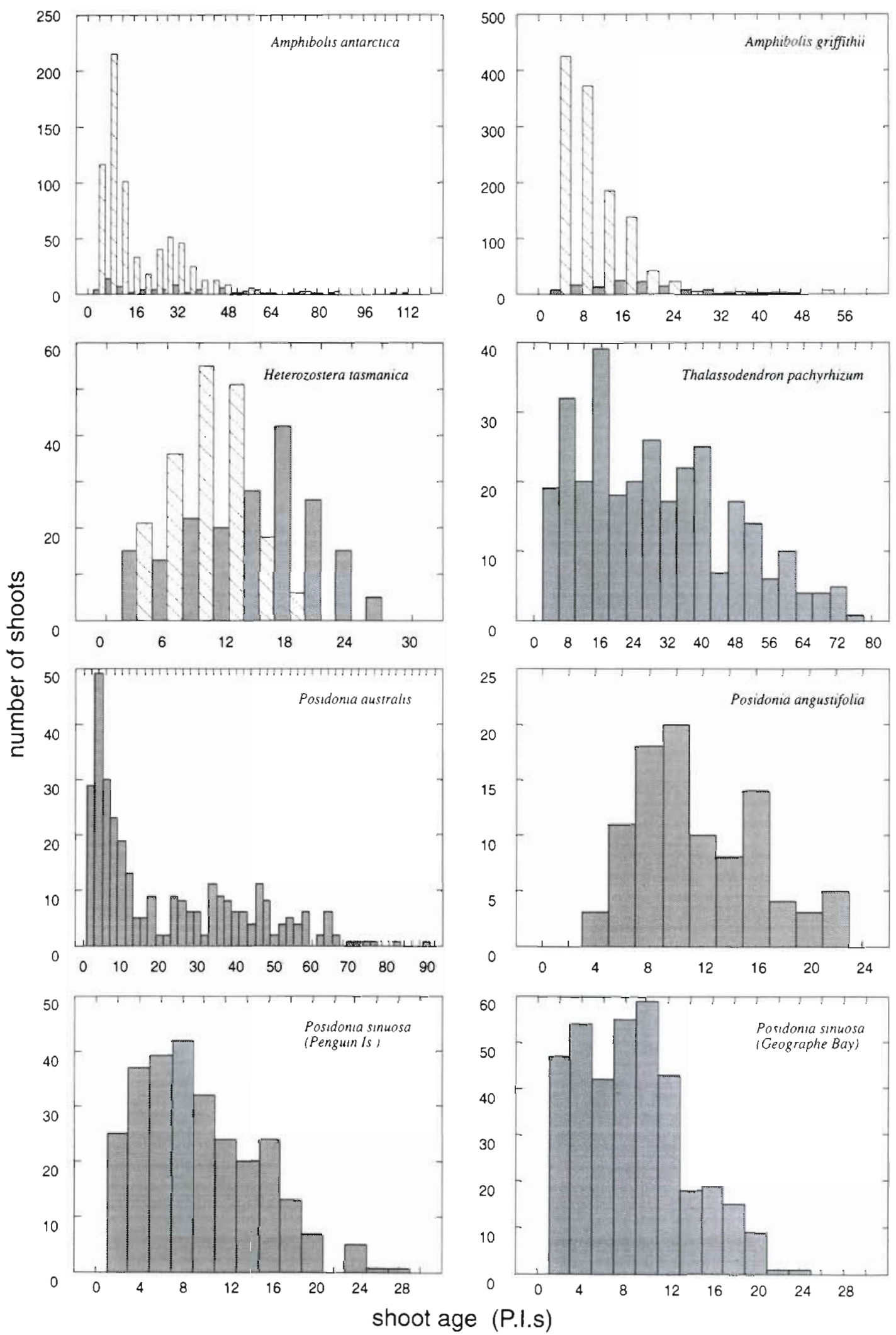

Fig. 5. Age distributions of the living short shoots in temperate Western Australlan seagrass meadows The abundance of main vertical stems (grey bars) and vertical branches (hatched bars) of Amphibolis antarctica, A. gnffithi, and Heterozostera tasmanica are indicated 
Table 5. Short shoot demography of temperate Western Australian seagrasses. Standard error of the mean values (within parentheses) is provided when available

\begin{tabular}{|c|c|c|c|c|c|c|c|c|}
\hline & \multicolumn{2}{|c|}{$\begin{array}{l}\text { Shoot } \\
\text { age (d) }\end{array}$} & \multirow{2}{*}{$\begin{array}{l}\text { Maximum } \\
\text { shoot life } \\
\text { expectancy } \\
\text { (d) }\end{array}$} & \multicolumn{2}{|c|}{$\begin{array}{l}\text { Shoot } \\
\text { recruitment } \\
\text { (ln units } \mathrm{yr}^{-1} \text { ) }\end{array}$} & \multicolumn{2}{|c|}{$\begin{array}{l}\text { Shoot } \\
\text { mortality rate } \\
\left.\text { (ln units } \mathrm{yr}^{-1}\right)\end{array}$} & \multirow[t]{2}{*}{$\begin{array}{c}\text { Meadow } \\
\text { state }\end{array}$} \\
\hline & ain stems & Branches & & Main stems & Branches & Main stems & Branches & \\
\hline Amphibolis antarctica & 406 & 126 & 1568 & 0.61 & 1.56 & $0.58(0.08)$ & $1.69(0.16)$ & Steady \\
\hline Amphibolis griffithii & 536 & 189 & 1673 & 0.34 & 1.65 & $1.08(0.22)$ & $1.32(0.15)$ & Steady \\
\hline Heterozostera tasmanica & 339 & 226 & 633 & 1.93 & 4.51 & $2.26(0.81)$ & $4.04(0.97)$ & Steady \\
\hline Thalassodendron pachyrhizum & \multicolumn{2}{|c|}{770} & 2341 & \multicolumn{2}{|c|}{0.50} & \multicolumn{2}{|c|}{$0.43(0.06)$} & Steady \\
\hline Posidonia australis & \multicolumn{2}{|c|}{652} & 4895 & \multicolumn{2}{|c|}{0.46} & \multicolumn{2}{|c|}{$0.37(0.03)$} & Steady \\
\hline Posidonia angustifolia & \multicolumn{2}{|c|}{367} & 1545 & \multicolumn{2}{|c|}{0.76} & \multicolumn{2}{|c|}{$1.22(0.12)$} & Declining \\
\hline Posidonia sinuosa (Penguin Is.) & \multicolumn{2}{|c|}{1123} & 3930 & \multirow{2}{*}{\multicolumn{2}{|c|}{$\begin{array}{l}0.18 \\
0.33\end{array}$}} & \multicolumn{2}{|c|}{$0.50(0.04)$} & Declining \\
\hline Posidonia sinuosa (Geographe $\mathrm{Ba}$ & \multicolumn{2}{|c|}{863} & 2591 & & & \multicolumn{2}{|c|}{$0.45(0.08)$} & Steady \\
\hline
\end{tabular}

vertical rhizomes of Amphibolis spp. and H. tasmanica had much shorter life-spans than those on the main stems (up to $1 / 4$, Table 5).

Short shoot recruitment during the previous year of sampling varied 10 -fold across the meadows examined (Table 5). The short shoots of Heterozostera tasmanica recruited at the fastest rate and those of Posidonia sinuosa at the slowest one. Most (76\%) of the variability in short shoot recruitment rates observed was coupled to the large differences in short shoot life-span across the meadows (Fig. 6). The abundances of short shoots in
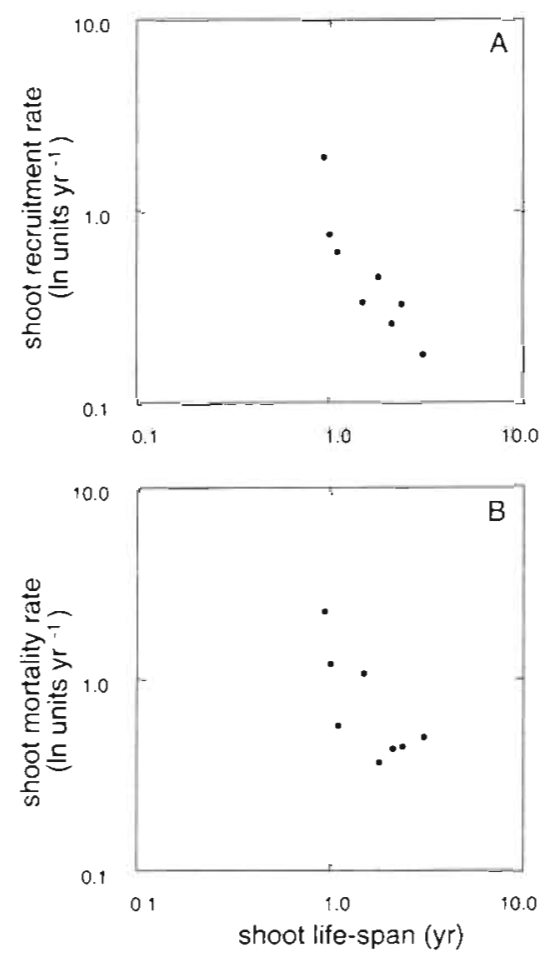

Fig. 6. Plots of (A) short shoot recruitment rate and (B) short shoot mortality rate, against short shoot life-span across temperate Western Australian seagrasses
Amphibolis spp. and $H$. tasmanica meadows were mainly maintained by fast recruitment rates of shoots by vertical rhizomes, which were up to 5 -fold faster than those achieved by horizontal ones (Table 5). In addition, recruitment rates of seagrass ramets were closely coupled to horizontal rhizome elongation rate (Pearson correlation, $r=0.87, p<0.0005$, Fig. 7).

Short shoot mortality rate in the seagrass meadows studied ranged from 0.37 to 4.04 ln units $\mathrm{yr}^{-1}$. Short shoot mortality was to a large extent ( $49 \%$ of the variance) coupled to short shoot life-span (Fig. 6). Short shoot recruitment balanced short shoot mortality in most of the meadows examined, indicating that the meadows were mainly in steady state (Table 5). However, the short shoot recruitment rates $1 \mathrm{yr}$ prior to sampling did not suffice to compensate short shoot mortality in Posidonia angustifolia and in $P$. sinuosa (Penguin Is.) meadows (Table 5), and a decline of short shoot density by $50 \%$ would be expected in 1.5 and 2 yr, respectively. The high density of horizontal rhizome apices found in the $P$. angustifolia meadow (Table 3), however, suggests that short shoot recruitment will increase in the future in this meadow.

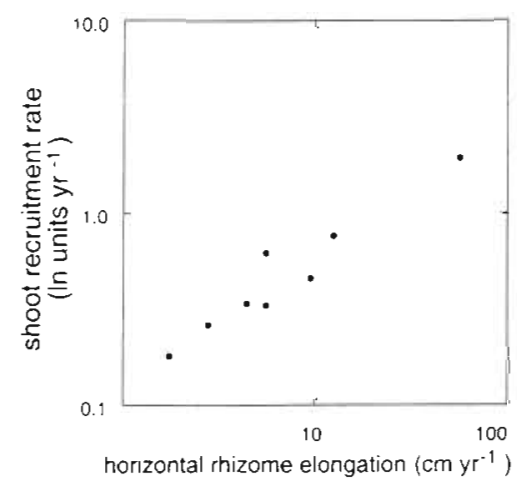

Fig. 7 Plot of ramet recruitment rate versus horizontal rhizome elongation rate across temperate Western Australian seagrasses 


\section{DISCUSSION}

Temperate seagrass species of Western Australia have different plant morphologies, display a wide repertoire of growth patterns, and exhibit substantial variability in their capacity to flower. Most of the species examined, however, are slow-growing plants. The variability in plant growth and flowering intensity indicates that Heterozostera tasmanica is the only seagrass amongst those studied here well fitted to play an effective pioneer role in Western Australian seagrass communities. The slow clonal growth and infrequent flowering of Posidonia sinuosa, conversely, confirms this species to be restricted to slow meadow development consistent with its climax role (Clarke \& Kirkman 1989).

The observed variability in seagrass growth mainly results from the particular growth of the species involved, since sympatric species (i.e. Posidonia australis and Amphibolis griffithii, P. angustifolia and Heterozostera tasmanica, Table 3) differ by 4 -fold in growth rate. The specificity of seagrass growth patterns reflects, in turn, the differences in plant size and shape among species. The cost of construction of seagrass modules increases exponentially with plant size (Duarte 1991). Hence, small seagrass species (e.g. $H$. tasmanica) require less resources to produce their modules, and are, therefore, able to grow faster than species built by large modules (e.g. P. australis). Amphibolis spp. and Thalassodendron pachyrhizum, however, spread their horizontal rhizomes at lower rates than predicted from the thickness of their rhizomes $\left(47 \mathrm{~cm} \mathrm{yr}^{-1}\right.$ in $A$. antarctica, $39 \mathrm{~cm} \mathrm{yr}^{-1}$ in A. griffithii, and $13 \mathrm{~cm} \mathrm{yr}^{-1}$ in $T$. pachyrhizum, cf. Marbà \& Duarte 1998), which has been demonstrated to be a good descriptor of seagrass size (Duarte 1991). The fast vertical rhizome growth of these species probably constrains their horizontal spread, indicating that seagrass growth patterns also depend on the overall plant architecture.

The large variability in flowering capacity observed among the seagrass meadows studied reflects specific variability in resource allocation to sexual reproduction. Studies on seagrass flowering intensity in Western Australian waters demonstrate that flowering is rare in Posidonia spp. (Cambridge \& Hocking 1997. Inglis \& Lincoln-Smith 1998) and in some Amphibolis antarctica meadows (Waycott et al. 1996), which mainly agrees with our findings. However, the studied $P$. australis meadow flowered profusely when compared with the sparse flowering reported for this species (Cambridge \& Hocking 1997, Inglis \& LincolnSmith 1998). The high flowering intensity of $P$. australis may reflect particular local environmental conditions such as cold water (Inglis \& Lincoln-Smith 1998), or intensive sediment dynamics, as observed in other seagrass species (Gallegos et al. 1992, Marbà \& Duarte 1995). Flowering shoots were also abundant in Thalassodendron pachyrhizum and Heterozostera tasmanica. The lack of studies on flowering in other T. pachyrhizum and $H$. tasmanica meadows precludes elucidating whether this is a common trait of these species.

Clonal growth is the main mechanism for providing short shoots in temperate Australian seagrass meadows, as demonstrated by the tight coupling between ramet recruitment rates and horizontal rhizome elongation (Fig. 7). Vertical rhizomes, moreover, act as the major source of shoot proliferation in some of the species studied (i.e. Amphibolis spp. and Heterozostera tasmanica). Variability in clonal growth across seagrass species allows small species, with relatively fast-growing rhizomes (e.g. H. tasmanica), to recruit short shoots 10 -fold faster than large, slow-growing ones (e.g. Posidonia sinuosa). Slow-growing seagrass species, however, compensate their low rates of short shoot proliferation by having long-living short shoots compared to species with fast shoot recruitment rates. The close scaling between rhizome elongation and short shoot recruitment rates to shoot life-span ensures the balance required between shoot production and decay in stable populations. Short shoot proliferation, however, decreases exponentially as shoot life-span increases (Fig. 6), involving a much slower flux, or turnover, of short shoots within populations of large, slow-growing seagrass species than small, fast-growing ones.

The aboveground biomass of seagrass meadows examined was within the ranges reported in other Australian localities (Kirkman \& Reid 1979, West \& Larkum 1979, Bulthius \& Woelkering 1981, Walker 1985, Silberstein et al. 1986, Kirkman \& Cook 1987, Walker \& McComb 1988, Bulthius et al. 1992, Carruthers 1994, Cambridge \& Hocking 1997). The variety of growth patterns of temperate Australian seagrasses and the fact that clonal growth, rather than seed production, controls short shoot population dynamics suggest that these species display different strategies to maintain the biomass of their meadows over interannual time scales. The small seagrass Heterozostera tasmanica, with fast-growing rhizomes and fast rates of short shoot proliferation, maintains its meadows by the continuous replacement of shoots. Indeed, the recruitment rate in the $H$. tasmanica meadow indicates that the vertical stems have a turnover of 5.8 times $\mathrm{yr}^{-1}$. In contrast, the large, slow-growing Posidonia sinuosa only replaces $40 \%$ of the shoots of the population within $1 \mathrm{yr}$, evidencing that the maintenance of meadow biomass over years is achieved mainly by the production of new leaves on old short shoots. Maintenance of Amphibolis spp. meadows, with plants of an intermediate size and vertical stems profusely branched, would rely on replacement of short shoots 
vegetatively produced by vertical stems. The shoots in the Amphibolis spp. meadows have a fast turnover, i.e. 4.6 times $\mathrm{yr}^{-1}$, but only 40 and $80 \%$ of the ramets are replaced annually in $A$ griffithii and $A$ antarctica, respectively. The wide seasonal fluctuations in short shoot density reported in $H$. tasmanica (Bulthius \& Woelkering 1981) meadows compared with the low ones in A. griffithii (Carruthers 1994) and Posidonia spp. (McMahon et al. 1997) confirm that the biomass of temperate Western Australian seagrass meadows is maintained through different plant growth strategies.

The persistence of temperate Australian seagrass meadows could, thus, exclusively rely on plant growth (i.e. leaf and clonal growth), if seagrass genets were everlasting, and if seagrass meadows were not altered by disturbances promoting important loss of seagrass cover. However, meadow maintenance probably also depends on genet formation rate, and, thus, on flowering intensity, the success of fertilisation, the number of seeds produced per flower, the number of seeds germinated and early seedling survival. Despite the importance of sexual reproduction for seagrass meadow dynamics, there is a lack of information about most of these aspects of seagrass ecology. The few studies available, however, indicate that abortion of flowers is low (Buia \& Mazzella 1991, Terrados 1993, Williams 1995) and flowers are currently pollinated (Verduin et al. 1996). Hence, the most critical factors in reproduction success of seagrass populations seem to be flowering and seedling survival, flowering intensity setting its upper threshold. The variability in flowering intensity across the meadows studied suggests that sexual reproduction may play a more important role for meadow persistence in some populations than in others. The profuse flowering in Thalassodendron pachyrhizum, Posidonia australis and Heterozostera tasmanica meadows indicates that these populations might be maintained by continuous formation of new genets. Conversely, sexual reproduction would have a negligible contribution to meadow maintenance in the Amphibolis antarctica, $P$. angustifolia and $P$. sinuosa populations studied, as very few genets are expected to be produced, and replaced, considering the low flowering rates of their short shoots. The differences in contribution of sexual reproduction for meadow maintenance among meadows might be reflected in the genetic structure of the populations. Examination of the genetic variability in this $P$. australis meadow revealed that it was a multiclonal population, and that it was composed of a high number of genotypes (15 different genotypes within an area of $320 \mathrm{~m}^{-2}$, Waycott 1995). In contrast, the studied $A$. antarctica meadow was genetically invariant (Waycott et al. 1996), indicating that this population was formed by a single or very few genotypes. Waycott et al. (1996) attributed the lack of genetic variability in this $A$, antarctica meadow to inbreeding rather than to low genet formation rate. However, the observed differences in flowering intensity among temperate Australian seagrass meadows seem to be coupled to their degree of genetic variability, indicative that the persistence of these seagrass meadows could also rely on different genet replacement rates. Stable meadows of $P$. australis, T. pachyrhizum and $H$. tasmanica may, therefore, be maintained by a flux of genets, whereas the persistence of those of Amphibolis spp., $P$. angustifolia and $P$. sinuosa would exclusively depend on clonal plant growth.

Most of the meadows examined here were in steadystate; the only decline in short shoot density was predicted for 2 populations as a consequence of recent low short shoot recruitment rates (Table 5, Fig. 5). This decrease in short shoot recruitment, and thus clonal growth, however, might simply reflect interannual environmental fluctuations involving a decline in plant growth, as observed for other seagrass components (i.e. leaves and rhizomes, Marbà \& Duarte 1998). However, Posidonia sinuosa, P. australis, Amphibolis antarctica and $A$. griffithii meadows elsewhere have experienced substantial declines of seagrass cover, mainly as a consequence of human activities (e.g. industrial and residence development and boat moorings: Cambridge \& McComb 1984, Shepherd et al. 1989. Walker et al. 1989, Larkum \& West 1990, Kendrick et al. in press). The slow clonal growth, and low flowering intensity, of some of these seagrass species (i.e. P. sinuosa, A. antarctica), as demonstrated in this study, predict that recovery of disturbed $P$. sinuosa, $A$. antarctica meadows should involve time scales of centuries. Despite the slow clonal growth of $A$. griffithii and $P$. australis, their high capacity to flower indicates that sexual reproduction may considerably speed up their recovery in disturbed meadows, and might explain the surprisingly fast recovery of the $A$. griffithii meadow observed on Success Bank (Western Australia, Kendrick et al. in press).

In summary, growth and flowering intensity vary among temperate Western Australian seagrass species, as a result of large differences in plant size and form. Maintenance of seagrass meadows is based on the continuous replacement of modules, short shoots and genets, which is constrained by the close scaling between production and life-span of seagrass components. The different growth programmes of seagrass species reveal that seagrass species display different plant strategies to maintain their meadows, and contrasting capacities to recover from disturbance. Moreover, the large differences observed in flowering intensity, which sets the upper threshold of sexual reproduction success, across temperate Western Australian seagrasses suggest an important role of sexual 
reproduction for meadow maintenance and recovery in some species. However, further studies quantifying the flux of genets through seagrass meadows are required to elucidate the real contribution of sexual reproduction in seagrass meadow dynamics.

Acknowledgements. This work was funded by CIRIT with a grant to N.M. We are grateful to Kath McMahon, Simon Montgomery, Jane Wilshaw, Cameron Sim and Emma Cole for assistance in the field, and Tim Carruthers and Tom Davis for assistance in the laboratory. We thank Gustavo Carreras for drawing Fig. 2, David Bird for statistical help, and Carlos M. Duarte for useful comments on the manuscript.

\section{LITERATURE CITED}

Akenasy E (1880) Uber eine neue Methode, um die Vertheilung der Wachsthumsintensität in wachsenden Theilen zu bestimmen. Verh Nathist-Med Ver Heidelbg 2:70-153

Buia MC, Mazzella L (1991) Reproductive phenology of the Mediterranean seagrasses Posidonia oceanica (L.) Delile, Cymodocea nodosa (Ucria) Aschers., and Zostera noltii Hornem. Aquat Bot 40:343-362

Bulthius DA, Woelkering WMJ (1981) Effects of in situ nitrogen and phosphorus enrichment of the sediments on the seagrass Heterozostera tasmanica (Martens ex Aschers.) den Hartog in Western Port, Victoria, Australia. J Exp Mar Biol Ecol 53:193-207

Bulthius DA, Axerlad DM, Mickelson MJ (1992) Growth of the seagrass Heterozostera tasmanica limited by nitrogen in Port Phillip Bay, Australia. Mar Ecol Prog Ser 89: 269-275

Cambridge ML, Hocking PJ (1997) Annual primary production and nutrient dynamics of the seagrasses Posidonia sinuosa and Posidonia australis in south-western Australia. Aquat Bot 59:277-295

Cambridge ML, McComb AJ (1984) The loss of seagrasses in Cockburn Sound, Western Australia. I. The time course and magnitude of seagrass decline in relation to industrial development. Aquat Bot 20:229-243

Carruthers TJB (1994) Leaf production, canopy structure and light climate of a density manipulated Amphibolis griffithii meadow. MSc thesis, University of Western Australia, Perth

Carruthers TJB, Walker DI (1997) Light climate and energy flow in the seagrass canopy of Amphibolis griffithii (J. M. Black) den Hartog. Oecologia 109:335-341

Clarke SM, Kirkman H (1989) Seagrass dynamics. In: Larkum AWD, McComb AJ, Shepherd SA (eds) Biology of seagrasses: a treatise on the biology of seagrasses with special reference to the Australian region. Elsevier/NorthHolland, Amsterdam, p 304-345

den Hartog C (1970) The seagrasses of the world. North-Holland, Amsterdam

Duarte CM (1991) Allometric scaling of seagrass form and productivity. Mar Ecol Prog Ser 77:289-300

Duarte CM, Sand-Jensen K (1990) Seagrass colonisation: patch formation and patch growth in Cymodocea nodosa. Mar Ecol Prog Ser 65:193-200

Duarte CM, Marbà N, Agawin N, Cebrian J, Enriquez S, Fortes MD, Gallegos ME, Merino M, Olesen B, SandJensen K, Uri J, Vermaat J (1994) Reconstruction of seagrass dynamics: age determinations and associated tools for the seagrass ecologist. Mar Ecol Prog Ser 107:195-209
Freund RJ, Littell RC (1991) SAS system for regression. SAS Institute Inc, Cary, NC

Gallegos ME, Marbà N, Merino M, Duarte CM (1992) Flowering of Thalassia testudinum in the Mexican Caribbean: age-dependence and interannual variability. Aquat Bot 43:249-255

Hillman K, Walker DI, McComb AJ, Larkum ADW (1989) Productivity and nutrient limitation. In: Larkum AWD, McComb AJ, Shepherd SA (eds) Biology of seagrasses: a treatise on the biology of seagrasses with special reference to the Australian region. Elsevier/North-Holland, Amsterdam, p 635-685

Hillman K, McComb AJ, Walker DI (1995) The distribution, biomass and primary production of the seagrass Halophila ovalis in the Swan/Canning Estuary, Western Australia. Aquat Bot 51:1-54

Inglis GL, Lincoln-Smith MP (1998) Synchronous flowering of estuarine seagrass meadows. Aquat Bot 60:37-48

Jeffrey SW (1981) Phytoplankton ecology with particular reference to the Australasian region. In: Clayton MN, King RJ (eds) Marine botany: an Australasian perspective. Longman Cheshire, Melbourne, p 241-291

Kendrick GA, Eckersley J, Walker DI (in press) Landscapescale changes in seagrass distribution over time: a case study from Success Bank, Western Australia. Aquat Bot

Kirkman H, Cook IH (1987) Distribution and leaf growth of Thalassodendron pachyrhizum den Hartog in southern Western Australia. Aquat Bot 27:257-266

Kirkman H, Reid DD (1979) A study of the role of the seagrass Posidonia australis in the carbon budget of an estuary. Aquat Bot $7: 173-183$

Kirkman H, Walker DI (1989) Regional studies-Western Australian seagrass. In: Larkum AWD, MCComb AJ, Shepherd SA (eds) Biology of seagrasses: a treatise on the biology of seagrasses with special reference to the Australian region. Elsevier/North-Holland, Amsterdam, p 157-181

Larkum AWD (1976) Ecology of Botany Bay. I. Growth of Posidonia australis Hook $F$, in Botany Bay and others bays of the Sydney Basin. Aust J Mar Freshw Res 27:117-127

Larkum AWD, den Hartog C (1989) Evolution and biogeography of seagrasses. In: Larkum AWD, McComb AJ, Shepherd SA (eds) Biology of seagrasses: a treatise on the biology of seagrasses with special reference to the Australian region. Elsevier/North-Holland, Amsterdam, p 112-156

Larkum AWD, West RJ (1990) Long-term changes of seagrass meadows in Botany Bay, Australia. Aquat Bot 37:55-70

Marbà N, Duarte CM (1995) Coupling of seagrass (Cymodocea nodosa) patch dynamics to subaqueous dune migration. J Ecol 83:381-389

Marbà N, Duarte CM (1998) Rhizome elongation and seagrass clonal growth. Mar Ecol Prog Ser 174:269-280

McMahon K, Walker DI (1998) Fate of seasonal, terrestrial nutrient inputs to a shallow seagrass dominated embayment. Estuar Coast Shelf Sci 46:15-25

McMahon $\mathrm{K}$, Young E, Montgomery S, Cosgrove J, Wilshaw J, Walker DI (1997) Status of a shallow seagrass system, Geographe Bay, south-western Australia. J R Soc West Aust 80:255-262

Sheil D, Burslem DFRP, Alder D (1995) The interpretation and misinterpretation of mortality rate measures. J Ecol 83 : 331-333

Sheperd SA, McComb AJ, Bulthuis DA, Neverauskas V, Steffensen DA, West R (1989) Decline of seagrasses. In: Larkum AWD, McComb AJ, Shepherd SA (eds) Biology of seagrasses: a treatise on the biology of seagrasses with special reference to the Australian region. Elsevier/NorthHolland, Amsterdam, p 346-391 
Silberstein K, Chiffings AW, McComb AJ (1986) The loss of seagrass in Cockburn Sound, Western Australia. III. The effect of epiphytes on productivity of Posidonia australis Hook F. Aquat Bot 24:355-371

Terrados J (1993) Sexual reproduction and seed banks of Cymodocea nodosa (Ucria) Ascherson meadows on the Southeast Mediterranean coast of Spain. Aquat Bot 46: 293-299

Tomlinson PB (1974) Vegetative morphology and meristem dependence. The foundation of productivity in seagrasses. Aquaculture 4:107-130

Verduin JJ, Walker DI, Kuo J (1996) In situ submarine pollination in the seagrass Amphibolis antarctica: research notes. Mar Ecol Prog Ser 133:307-309

Walker DI (1985) Correlations between salinity and growth of the seagrass Amphibolis antarctica (Labill.) Sonder \& Aschers., in Shark Bay, Western Australia, using a new method for measuring production rate. Aquat Bot 23:13-26

Walker DI, McComb AJ (1988) Seasonal variation in the pro-

Editorial responsibility: Otto Kinne (Editor),

Oldendorf/Luhe, Germany duction, biomass and nutrient status of Amphibolis antarctica (Labill.) Sonder \& Aschers. and Posidonia australis Hook. F in Shark Bay, Western Australia. Aquat Bot 31: $259-275$

Walker D, Lukatelich RJ, Bastyan G, McComb AJ (1989) Effect of boat moorings on seagrass beds near Perth, Western Australia. Aquat Bot 36:69-77

Waycott M (1995) Assessment of genetic variation and clonality in the seagrass Posidonia australis using RAPD and allozyme analysis. Mar Ecol Prog Ser 116:289-295

Waycott M, Walker DI, James SH (1996) Genetic uniformity in Amphibolis antarctica, a dioecious seagrass. Heredity 76 $578-585$

West RJ, Larkum AWD (1979) Leaf productivity of the seagrass Posidonia australis in Eastern Australian waters Aquat Bot 7:57-65

Williams SL (1995) Surfgrass (Phyllospadix torreyi) reproduction: reproductive phenology, resource allocation and male rarity. Ecology 76:1953-1970

Submitted: October 21, 1998; Accepted: March 16, 1999 Proofs received from author(s): June 23, 1999 